\title{
Public policy recommendations for promoting female entrepreneurship in Europe
}

\author{
Isabel Martínez-Rodríguez ${ }^{1}$ (D) · Consolación Quintana-Rojo ${ }^{1} \cdot$ Pedro Gento $^{1}$. \\ Fernando-Evaristo Callejas-Albiñana ${ }^{1} \mathbb{D}$
}

Accepted: 30 March 2021 / Published online: 4 May 2021

(C) The Author(s), under exclusive licence to Springer Science+Business Media, LLC, part of Springer Nature 2021

\begin{abstract}
From 2021 onwards, female entrepreneurship is expected to grow very substantially as a result of the Covid-19 pandemic. The introduction of teleworking and staggered hours in many countries at national or workplace level will make possible the conciliation between labour and family life. The purpose of this paper is to identify the most influential explanatory factors in the behaviour of female entrepreneurship in Europe so as to subsequently propose efficient economic policy measures to promote it. The distinction between opportunity and necessity female entrepreneurs have been considered since both motivation and factors are different in each case. 15 econometric models using the panel data method for a sample of 20 previously selected European countries (grouped by their GDP level) during the period 2001 to 2018 have been estimated to determine which explanatory factors affect female entrepreneurship and necessity-based female entrepreneurship. The empirical analysis used demonstrates that more women enter into entrepreneurship due to necessity rather than in pursuit of opportunity for European countries both with higher levels of GDP and for countries with lower levels of GDP. In this context, the following policy measures should be implemented to promote female entrepreneurship in Europe: the optimization of government spending (training courses and mentoring, public procurement, stronger networks, support in reconciling business and family life, etc.), the government incentives for subsidizing high interest rates to support women in accessing financing, and the improvement of entrepreneurship education to increase the confidence of women in themselves in their own entrepreneurial capabilities.
\end{abstract}

Keywords Female $\cdot$ Entrepreneurship $\cdot$ Necessity $\cdot$ Opportunity $\cdot$ Explanatory factors · Development · GDP

Isabel Martínez-Rodríguez

isabel.mrodriguez@uclm.es

Extended author information available on the last page of the article 


\section{Introduction}

Worldwide, females are showing a considerable interest in entrepreneurship, resulting in more females establishing new business ventures (Meyer, 2018; Wu et al., 2019; Hechavarria et al., 2019). Female entrepreneurship has recently been established as a priority for the governments of the world's main economies due to the benefits that both developed and underdeveloped countries can gain from it (Rubio-Bañón \& Esteban-Lloret, 2016; Hechavarria et al., 2019). Although women's social and economic participation in the work environment has advanced substantially in the last few decades, several new policy approaches to supporting women in entrepreneurship are starting to emerge (OECD, 2017), specially during the Covid-19 pandemic (European Commission, 2020a).

From 2021 onwards, entrepreneurship is expected to grow very substantially, especially female entrepreneurship. The Covid-19 pandemic has affected the many advanced economies labor market model. For instance, teleworking and staggered hours are being introduced in many countries at national or workplace level (ILO, 2020) making possible the conciliation between labour and family life. As a result, female entrepreneurship is likely to increse.

Given this situation, the main objective of this work is to identify the most influential social, institutional and financial factors in the behaviour of female entrepreneurship in Europe so as to subsequently propose efficient economic policy measures to promote it.

To achieve the objective, Sect. 2 will examine the current increasing interest in the role of woman in entrepreneurial activity by policy makers and scholars (Brush et al., 2020; Wassem, 2018). Section 3 will explain the difference between necessity-driven entrepreneurship and opportunity-driven entrepreneurship and will consider the reasons for starting a business among females. This distinction is important because by understanding the real reasons why women decide to start a business, more efficient economic policies can be designed to promote their activity.

Section 4 will then review the literature on some of the key explanatory factors driving necessity- and opportunity-based female entrepreneurship. Section 5 will estimate 15 econometric models using the panel data method during the period 2001 to 2018. The models are run using a sample group of 20 European countries (classified by higher or lower levels of development -level of GDP at absolute values-) and explanatory factors considered to be the most characteristic of female entrepreneurship and of necessity-based female entrepreneurship. The aim is to determine which is the predominant motivation (necessity vs. opportunity) and to identify which explanatory factors are determinant for each situation so as to subsequently propose efficient economic policy measures to promote female entrepreneurship in each particular case. Finally, Section 6 contains conclusions and policy implications for promoting female entrepreneurship in Europe that are derived from the empirical studies presented in this research. 


\section{The relevance of female entrepreneurship}

Today, the figure of the entrepreneur is increasingly important in our society and entrepreneurship has become a primary objective of governments of the world's leading, emerging and advanced economies due to its positive impact on wealth and employment (Thurik et al., 2008; Sugheir et al., 2013; Doran et al., 2016; Åstebro \& Tåg, 2017), which in turn increases productivity, and encourages innovation (Audretsch, 2007; Cuervo et al., 2007) by enhancing competitiveness (Pradhan et al., 2020) and generating long-term economic growth (Doran et al., 2018; Galindo-Martín et al., 2019; Urbano et al., 2019; Pradhan et al., 2020). Furthermore, recent literature highlights that entrepreneurial activity not only leads to sustained economic growth and a persistent rise in living standards through innovation and enhanced competitivity, but it can also reduce income inequality and even promote social fairness and justice (Stoica et al., 2020).

In this research, we intend to analyze the case of female entrepreneurship. This consideration is important because contemporary research has shown that there are some differences between men and women when it comes to entrepreneurship (Shmailan, 2016).

The interest in women's entrepreneurship is relatively recent. Up until the late 1970s, the role of women entrepreneurs was rarely considered (Humbert et al., 2010). It was only then when researchers started to recognize that "entrepreneurship is a gendered phenomenon" (Jennings \& Brush, 2013). Nowadays, there is a consistent opinion among both policy makers and scholars that women entrepreneurship in last decades has grown significantly all over the world (Cabrera \& Mauricio, 2017; OCDE, 2017; Ratten \& Dana, 2017). Thus, research on women entrepreneurship has attracted their attention (Eddleston et al., 2016; Ramadani et al., 2015; Shmailan, 2016; Wassem, 2018; Brush et al., 2020).

If we accept that gender is embedded both in how society is structured and in individual choices (Lykke, 2010), it is key to study its impact on entrepreneurial behaviour. This is even more interesting if we consider that, in recent years, there has been a growth in the number of business start-ups by women and that, for this reason, governments have devised different policies to encourage female participation in entrepreneurial activities (Wassem, 2018). Despite this growing interest, women's entrepreneurial potential has only started to materialize (Malach-Pines et al., 2010).

The growing interest on the part of policy makers and scholars in the role of entrepreneurial women is due to the positive effects that an increase in the rate of female entrepreneurs generates in the economic conditions and social well-being of a country (Allen et al., 2008; Wiklund et al., 2019), both in developed and underdeveloped countries (Rubio-Bañón \& Esteban-Lloret, 2016). Specifically, in the case of under-developed countries, it is particularly relevant as it can act as a practical solution to reduce poverty (Sarfaraz et al., 2014; Doran et al., 2018).

Fortunately, women's rights and roles have evolved and progressed over recent decades and the negative viewpoint of most societies about women's attainment 
of independence and wealth is being left behind (Antai \& Anam, 2016). Women are increasingly educated, empowered politically and given economic freedoms (McGowan et al., 2012), which has radically accelerated the number of female entrepreneurs in recent years around the globe (Powell, 2011; Weiler \& Bernasek, 2001). Furthermore, studies have found that the determinants of survival and success operate in much the same way for men and women, suggesting that the processes underlying small business performance are similar regardless of gender (Minniti \& Arenius, 2003).

Nevertheless, female entrepreneurs continue to face multiple obstacles in their journey (Tewoldebirhan \& Joseph, 2019). As such, economic policies should support women in order to promote the development of total entrepreneurial activity, thereby generating economic growth (Rubio-Bañón \& Esteban-Lloret, 2016; Hechavarria et al., 2019).

\section{Necessity and opportunity drivers of female entrepreneurship}

Since 2001, the Global Entrepreneurship Monitor (GEM) project has differentiated between two different types of entrepreneurial activity: entrepreneurship driven by "necessity", and entrepreneurship driven by "opportunity" (Block \& Wagner, 2010; Reynolds et al., 2005). While there are many other secondary motivations that can influence the decision to become an entrepreneur, such as mixed motivations (a combination of opportunity and necessity or having a job but looking for better opportunitites) (Block \& Wagner, 2010), necessity-driven and opportunity-driven are the two main kinds and will, therefore, be considered in this research.

On the one hand, necessity-driven entrepreneurs are pushed to start businesses because they have no other job options and need a source of income (Peña et al., 2015). Although they largely arise as a result of purely economic motivations (Block \& Wagner, 2010; Hessels \& van der Zwan, 2013), based on the need for survival (Carsrud \& Brännback, 2010), they may also be motivated by occupational safety concerns (Tyszka et al., 2011) or their own professional or personal dissatisfaction (Noorderhaven et al., 2004).

Opportunity-driven entrepreneurs, on the other hand, choose to start or create a business based on the perception that there is a business opportunity that has not yet been taken advantage of (or which has not been fully taken advantage of) by existing companies (Peña et al., 2015). They are generally driven by both economic motivations, associated with the desire to increase their income (Carter et al., 2003) and gain of power, prestige, and/or status (Carsrud \& Brännback, 2010), in addition to non-economic motives (Block \& Wagner, 2010; Hessels \& van der Zwan, 2013), such as the need for independence and achievement (Amorós \& Guerra, 2009; Tyszka et al., 2011), or the aspiration to create their own business, be their own boss, and develop new products (Carter et al., 2003).

This distinction is necessary as not all entrepreneurial initiatives contribute to economic growth in the same way. Generally, opportunity-driven entrepreneurs have a greater positive impact on economic growth (Urbano et al., 2019), since they are comparable to larger companies with higher business volumes (Block 
\& Wagner, 2010; Fairlie \& Fossen, 2018), and higher growth expectations than necessity-driven entrepreneurs (Poschke, 2013). The latter are more likely to be located in lower-income regions with limited access to human capital, financial capital, technology, and other resources, which inhibits their potential to innovate and generate employment (Hessels et al., 2008, p. 327).

Women and men have differing reasons for starting a business (Moore \& Buttner, 1997). Shapero and Sokol (1982) were the first to distinguish between necessity-driven and opportunity-based entrepreneurship among females. This distinction is important in order to benefit from the participation of women in entrepreneurial activities (Wassem, 2018), because by understanding the real reasons why women decide to start a business, more efficient economic policies can be designed to promote their activity. However, some evidence on relationship between woman entrepreneurship and necessity/opportunity-driven entrepreneurship has already been provided by empirical studies, but it is often quite ambiguous (Holienkaa et al., 2016).

For example, some of the extant literature agrees that more women enter into entrepreneurship due to necessity rather than the pursuit of opportunity. For instance, family conciliation (Baughn et al., 2006; Malach-Pines et al., 2010; Minniti \& Naudé, 2010), the exclusion of women in the labour market (MalachPines et al., 2010), or the labour market inequalities (Noguera et al., 2015) may push some women to become entrepreneurs. Women at low-income levels may be pushed towards necessity-based entrepreneurship as a substitute for traditional wages/ salaried employment (Maniyalath \& Narendran, 2016), as is often the case for single mothers (Jennings \& Brush, 2013). Moreover, when women feel that they are earning less income than desired or anticipated, or the working conditions are poor, they tend to start their own businesses (Noguera et al., 2015).

However, some other arguments defend the possibility that women may decide to start their businesses driven by opportunity (Sörensson \& Dalborg, 2017; Ndikubwimana et al., 2020). They can be motivated by independence, autonomy, job loss, dissatisfaction with their current job or low career growth, more income, a lack of positive environment, the lack of recognition coupled with a need for achievement and personal growth (Goby \& Erogul, 2011; Ramadani et al., 2015) flexibility and control over one's career, recognition, and self-fulfillment (Jennings \& Brush, 2013). For instance, women regard flexibility and childcare obligations as strong motivators to become entrepreneurs (McGowan et al., 2012). Likewise, women now seek financial independence to engage in opportunitybased entrepreneurship. This trend has in turn led to more entrepreneurial initiatives from women who believe that they can earn more from their own businesses compared to traditional wages/ salaried employment (Wassem, 2018).

Finally, it is important to consider those integrative findings that suggests that necessity and opportunity are not two discrete motivations. They argue in terms of a combination of various pull (through necessity) and push (through opportunity) factors often motivating women to make the best use of opportunities that come their way (Goby \& Erogul, 2011). 


\section{Explanatory factors of female entrepreneurship}

In the task of studying female entrepreneurship and distinguishing between what is necessity- and opportunity-driven, it is crucial to define how these could be affected by different economic, social, and cultural factors. Research has shown that there are some characteristics that are found in both men and women but there are also some distinct differences that exist between the two (Shmailan, 2016). It is imperative to consider this, in particular where governments and policy makers are concerned, due to the implementation of policies for encouraging female entrepreneurs, in addition to the level of entrepreneurial activities in a given country and, therefore, the potential improvement for economic growth therein (Sarfaraz et al., 2014).

The following are some of the factors that may be taken into consideration when becoming an entrepreneur: human capital, perceived capabilities, a country's level of development, and institutional and financial factors. Albeit men may be equally influenced and affected by these factors, in the context of this study, we will look at the effects that they have upon women.

\section{Human capital}

Human capital, defined as the skills and knowledge that individuals acquire through investments in education, on-the-job training, and other types of experience (Becker, 1964), is a key factor for entrepreneurship. However, despite being a widely researched topic (Oosterbeek et al., 2010; Peterman \& Kennedy, 2003), there is no evidence of a systematic relationship between the level of human capital and the probability of becoming an entrepreneur since economic theory points out that education has two opposite effects (van Der Sluis et al., 2008).

Some authors argue that the individual with the highest level of human capital has skills and attitudes that will encourage him/her to be an entrepreneur (Barba-Sánchez \& Atienza-Sahuquillo, 2018; Herrera et al., 2018), such as selfconfidence (Kim et al., 2006; Shane \& Venkataraman, 2000), lower risk aversion (Shane \& Venkataraman, 2000; Ucbasaran et al., 2008), the agility (Westhead et al., 2005) to identify and discover business opportunities (Hajizadeh \& Zali, 2016; Qian et al., 2016; Sánchez, 2011), evaluate them and exploit them (Shane \& Venkataraman, 2000).

On the contrary, contributions can be highlighted that ensure that the level of education does not have a significant impact on the preferences for being an entrepreneur (Goby \& Erogul, 2011; Jones \& Jayawarna, 2010), with this relationship being over-emphasized (Baum \& Silverman, 2004; Nabi et al., 2010). Other noncognitive skills such as social skills or creativity (Ward, 2004; Weitzel et al., 2010; Zhao \& Seibert, 2006), are much more decisive in the decision to become an entrepreneur. With a higher level of human capital, the individual will prefer the security of a salary according to his/her qualifications with good conditions against the 
risk and uncertainty associated with self-employment (van Der Sluis et al., 2008; Millán \& Congregado, 2014; Galindo-Martin et al., 2010).

This lack of consensus in the relationship between human capital and entrepreneurship may be due to differences in the motivation, whether through necessity or opportunity. It has been shown that necessity-driven entrepreneurs are more likely to lack entrepreneurial skills, experience, and high levels of education (Block \& Wagner, 2010). Human capital is an important factor in identifying more and better opportunities and promoting entrepreneurship (Marques, 2017; Nasiri \& Hamelin, 2018).

Although all these assessments can be applied to both men and women, the way in which they may make use of stocks of human capital to identify opportunities may differ (DeTienne \& Chandler, 2007). Human capital is an important determinant for females to engage in entrepreneurship and has been extensively used to predict female propensity towards entrepreneurship (Wassem, 2018, p. 135).

\section{Perceived capabilities}

Beyond the level of human capital, the perception of one's own abilities to start a business is a differential component of entrepreneurship according to gender (Álvarez et al., 2012). Entrepreneurs often perceive their own abilities as crucial to the success of their business (Cooper et al., 1988; Hsu et al., 2019). It is thus also important for individuals to be able to recognize that they effectively possess the knowledge and skills necessary to be an entrepreneur (Peña, Guerrero \& González-Pernía, 2015). Specifically, women's motivation in launching business ventures depends upon the level of their self-assessment of their abilities and knowledge (Brush et al., 2017), and a lack of confidence reduces the growth of women's businesses (Carter, 1993).

For instance, at the European Union-level, women were less likely than men to feel that they had the skills, knowledge and experience to start a business over the 2010-14 period. This gender gap held across all EU Member States (OECD, 2017).

\section{Institutional and financial factors}

Access to capital plays an important role in entrepreneurship, and yet it is one of an entrepreneur's most challenging problems (Hwang et al., 2019). It is important to facilitate entrepreneur's access to capital because this has a positive impact on income, well-being, economic growth (Anton \& Bostan, 2017), as well as the progress of female entrepreneurs (Halabisky, 2018).

In this regard, although women have made progress in gaining similar access to financing as men, some recent studies have indicated that gendered biases exist that prevent them from being equally funded when demonstrating their business's viability and commitment (Bigelow et al., 2014; Shmailan, 2016; Halabisky, 2018). Evidence suggests that females encounter greater barriers in gaining access to funding (Alsos \& Ljunggren, 2017; Hwang et al., 2019; Marlow \& Patton, 2005; Muravyev et al., 2009), they receive smaller loan amounts in comparison to their male counterparts (Treichel \& Scott, 2006; Verheul \& Thurik, 2001), and that they are often 
charged higher interest rates (Wu \& Chua, 2011). For this reason, female entrepreneurs establish firms with significantly less financial capital than men do (Treichel \& Scott, 2006; Shaw et al., 2009). Sometimes the discrimination is not so evident, and it appears that covert and implicit biases exist that create barriers for women (Eddleston et al., 2016).

On the one hand, the discrepancy regarding the amount of capital raised by male versus female entrepreneurs can be caused by the discrimination of institutions. Studies suggest that the legitimacy, commitment and credibility, as well as the venture's viability and quality of female entrepreneurs are often questioned by capital providers (Greene et al. 2001; Eddleston et al., 2017). Women entrepreneurs need to share greater information than male entrepreneurs to obtain financing (Murphy et al., 2007) because the evaluative criteria applied by bank loan officers are different to the detriment of women (Constantinidis et al., 2006). On the other hand, the discrepancy can also be attributed to a lack of confidence in their own entrepreneurial capabilities (Minniti \& Arenius, 2003). This may lead them to perceive that bankers have a negative view of their creditability and reject them (Carter et al., 2006; Hill et al., 2006).

Recent research, however, has shown that gender differences in obtaining financial capital are diminishing (Becker-Blease \& Sohl, 2007; Carter et al., 2007), or even disappearing (Orser et al., 2006; Wilson et al., 2007; Eddleston et al., 2016).

In general, without considering the impact of gender, it can be concluded that necessity-driven entrepreneurs, who tend to be linked to small companies, with lowincome levels, solvency and, therefore, fewer collateral assets, will face more difficulties in gaining access to bank credit and alternative sources of financing (Block \& Wagner, 2010; Poschke, 2013). Moreover, a monetary restriction could be more worrisome for them, as they depend heavily on short-term financing by banks (Vendrell, 2012), and trade credit (Coleman, 2000).

\section{The country's level of economic development (GDP at absolute values)}

In this research the indicator Gross Domestic Product (at absolute values) has been used as a measure of economic development as the economic growth is a complementary indicator to development, and it is measured popularly via GDP. This indicator estimates the value added in a country which is the total value of all goods and services produced in a country minus the value of the goods and services needed to produce them. Thus, GDP is the single most important indicator to capture economic activity and a feedback effect can be accepted: activity promotes entrepreneurship and innovation activities, and the latter enhances economic activity (Galindo-Martin \& Méndez-Picazo, 2014). 
Although the phenomenon of female entrepreneurship is present in all countries, there is a considerable variation among different countries (Estrin \& Mickiewicz, 2011) because their level of economic growth (Fairlie \& Fossen, 2018) and development can affect both the rates of entrepreneurial efforts and their type (Sternberg \& Wennekers, 2005; van Stel et al., 2005). Specifically, the national income level plays a critical role in deciding whether female entrepreneurship is necessity-driven or opportunity-based (Terjesen \& Amorós, 2010).

The occurrence of necessity entrepreneurship can be expected to be related to the early development stage of an economy (Koster \& Rai, 2008). Women in low-income countries engage in necessity-based entrepreneurship due to economic necessities, survival needs, a way out of poverty (Naudé, 2011; Terjesen \& Amorós, 2010), health requirements and family education (Jennings \& Brush, 2013; Wassem, 2018), the need for selfsupport and lack of employment opportunities (Amorós et al., 2019).

A country's level of economic growth and development is positively related to the probability that individuals will engage in opportunity-based entrepreneurship (Fairlie \& Fossen, 2018; Amorós et al., 2019). As economies develop, the number of people who might engage in necessity-based entrepreneurship to meet their basic needs decreases because economic development is correlated with poverty reduction and an improved standard of living (Acs, 2006). Higher income level countries have auspicious economic conditions that offer more entrepreneurial opportunities for women. They can benefit from stronger institutions, along with easy access to human and monetary capital. Therefore, women in high-income level countries enter into opportunity-driven entrepreneurship due to frustration in career advancement (Lerner, \& Malach-Pines, 2011), because of their need for achievement, or their desire for independence, self-efficacy, and self-reliance (Wassem, 2018).

The empirical aim of this paper is to analyse the necessity- and opportunity-based female entrepreneurship in European countries. Although all the countries which have been analysed are developed, their level of Gross Domestic Product (GDP) at absolute values have been also considered as way of determining the level of economic activity and thus the level of economic growth.

In light of these considerations, the following hypotheses are proposed:

H1:Females are more likely to engage in opportunity-based entrepreneurship rather than necessity-based entrepreneurship in European developed countries (GDP at absolute values).

$\mathrm{H} 2$ : The explanatory socio-economic factors that determine necessity-based female entrepreneurship differ for the European country's level of development (GDP at absolute values). 


\section{Empirical analysis}

\section{Methodos and data}

The empirical work was carried out using the statistical method of panel data analysis. The information provided by the GEM database ${ }^{1}$ on total entrepreneurial activity (TEA) was taken as a reference, using 20 European countries (sufficient statistical information) and time series from 2001 to 2018 (GEM, 2020). The proposed models consider four types of entrepreneurship: Total Entrepreneurial Activity (TEA), Female Total Entrepreneurial Activity (FTEA), Female Opportunity-Driven Entrepreneurial Activity (FOTEA), Necessity-Driven Female Total Entrepreneurial Activity (FNTEA), to be dependent variables; the rest are considered proxy variables of socio-economic explanatory factors: human capital, perceived capabilities, institutional and financial factors and the country's level of development. In this study we constructed and validated models of the behavior of female entrepreneurs in European countries at different levels of development. The aim is to determine which is the predominant motivation (necessity vs. opportunity) and to identify which explanatory factors are determinant for female entrepreneurship (FTEA) so as to subsequently propose efficient economic policy measures to promote it and, consequently, stimulate economic growth.

The empirical analysis procedure is shown in Fig. 1.

The proxy variables for the explanatory economic and social factors (human capital, perceived capabilities, institutional and financial factors) (with sufficient data) were collected, as explained in the literature review above. Table 1 shows all the proxy variables ${ }^{2}$ considered to represent the effect of explanatory factors on entrepreneurship.

Likewise, the sample has been divided according to the country's level of development in order to be more concrete and precise in the results and to obtain valid conclusions for more national economies. This division has been made by obtaining the GDP average of all countries and by classifying in the sample accordingly: (1) all countries, (2) higher development countries (those countries for which their GDP average from 2001 to 2018 is above the total average GDP for the group) (3) lower development countries (those countries for which their GDP average from 2001 to

\footnotetext{
1 GEM began in 1999 as a joint research project between Babson College (USA) and London Business School (UK). The consortium has become the richest source of reliable information on the state of entrepreneurship and entrepreneurial ecosystems across the globe, publishing not only the GEM Global Report annually, but also a range of national and special topic reports each year. GEM's first annual study covered 10 countries, since then some 115 countries from every corner of the globe have participated in GEM research. As a result, GEM has gone beyond a project to become the highly networked organization that it is today. GEM can confidently stake a claim to be the largest ongoing study of entrepreneurial dynamics in the world (GEM, 2020).

${ }^{2}$ During the specification process, different combinations of all proxy variables were tried to produce the optimum models, but only significant variables were included in the final regression models estimated (see Tables 4-10). All the descriptive statistics and contrast tests were analyzed during the process.
} 


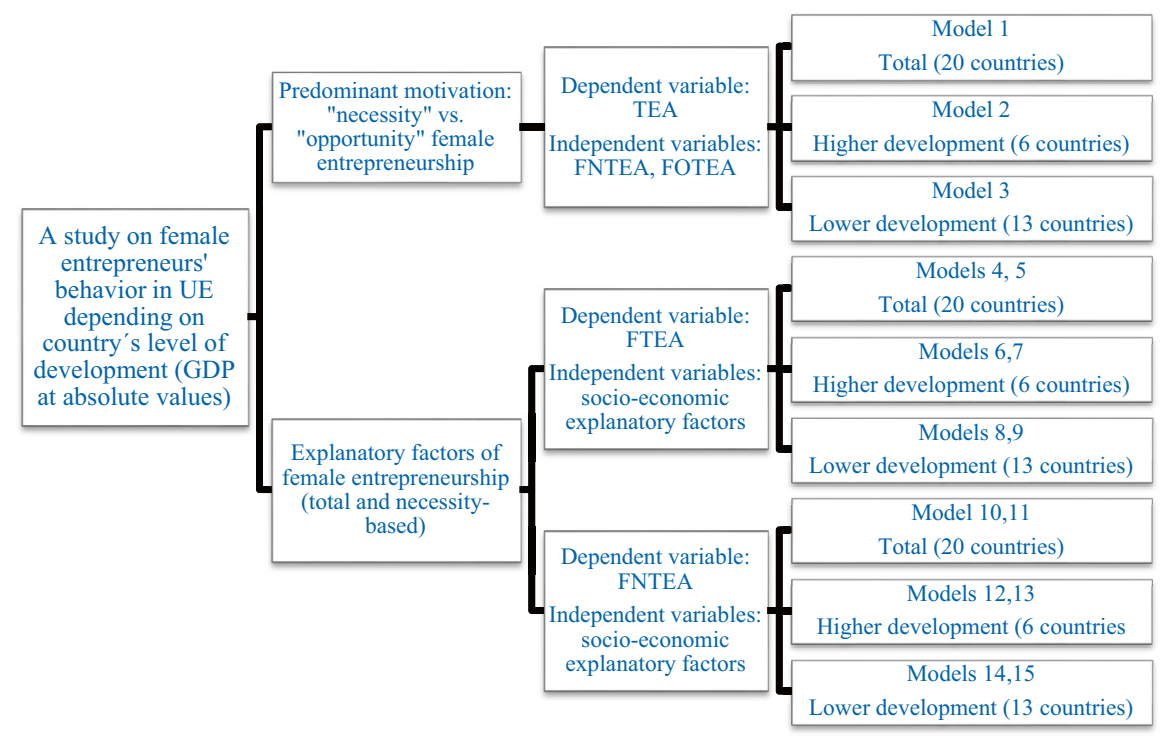

Fig. 1 Empirical analysis procedure

2018 is below the total average GDP for the group). ${ }^{3}$ Table 2 presents the countries considered for each exploratory model.

\section{Results and discussion}

Panel data regressions were run to test the hypotheses. The regression model results are shown in Tables 4 to 5. Table 3 summarizes the structure of the empirical analysis with the models' estimated classification. During the specification process, different combinations of all proxy variables collected (see Table 1) were tried in order to produce the optimum model (by analyzing descriptive statistics and contrast tests), however, only significant variables were included in the final regression models estimated (Tables 4, 5).

First, an exploratory econometric model of total entrepreneurial activity (TEA) was proposed. This is important to determine which entrepreneurial motivation (necessity vs. opportunity) is dominant among female entrepreneurship and which one explains the TEA to a greater extent depending on the country's level of development (measured

\footnotetext{
${ }^{3}$ The variable Gross domestic product (GDP) is measured at purchaser prices and it represents the sum of value added by all its producers in the economy plus any product taxes and minus any subsidies not included in the value of the products. The data processing has been: $1^{\circ}$ ) The GDP (at absolute values, US $\$$ current prices) average from 2001 to 2018 by country ( 20 countries) is calculated. $2^{\circ}$ ) The total average of these 20 individually GDP averages is calculated. $3^{\circ}$ ) This overall average is the reference value to classify the countries accordingly: (a) higher development countries: those countries for which their GDP average from 2001 to 2018 is above the reference value (b) lower development countries: those countries for which their GDP average from 2001 to 2018 is below the reference value.
} 
Table 1 Proxy variables (initial) for the socio-economic explanatory factors affecting FTEA

\begin{tabular}{|c|c|c|c|}
\hline $\begin{array}{l}\text { Socio-economic } \\
\text { explanatory factor }\end{array}$ & $\begin{array}{l}\text { Proxy vari- } \\
\text { able }\end{array}$ & Concept & Database \\
\hline \multirow[t]{5}{*}{ Entrepreneurship } & TEA & $\begin{array}{l}\text { Total Early-Stage Entrepreneurial Activity (\%). } \\
\text { Percentage of } 18-64 \text { population who are either a } \\
\text { nascent entrepreneur or owner-manager of a new } \\
\text { business }\end{array}$ & \multirow[t]{5}{*}{ GEM } \\
\hline & MTEA & Male Early-Stage Total Entrepreneurial Activity (\%) & \\
\hline & FTEA & $\begin{array}{l}\text { Female Early-Stage Total Entrepreneurial Activity } \\
(\%)\end{array}$ & \\
\hline & FOTEA & $\begin{array}{l}\text { Female Opportunity-Driven Early-Stage Entrepre- } \\
\text { neurial Activity (\%) }\end{array}$ & \\
\hline & FNTEA & $\begin{array}{l}\text { Necessity-Driven Female Total Early-Stage Entre- } \\
\text { preneurial Activity }(\%)\end{array}$ & \\
\hline \multirow[t]{3}{*}{ Human capital } & $\mathrm{HCF}$ & $\begin{array}{l}\text { Human capital female (Progression to secondary } \\
\text { school refers to the number of new entrants to the } \\
\text { first grade of secondary school in a given year as } \\
\text { a percentage of the number of students enrolled in } \\
\text { the final grade of primary school in the previous } \\
\text { year (minus the number of repeaters from the last } \\
\text { grade of primary education in the given year) }\end{array}$ & \multirow[t]{3}{*}{$\mathrm{OECD}^{\mathrm{a}}$} \\
\hline & TEDF & $\begin{array}{l}\text { Adult education level. Tertiary education in woman } \\
\text { (the highest level of education completed by the } 25 \\
-64 \text { year-old population) }\end{array}$ & \\
\hline & TEDT & $\begin{array}{l}\text { Adult education level. Tertiary education total (the } \\
\text { highest level of education completed by the } 25- \\
64 \text { year-old population) }\end{array}$ & \\
\hline $\begin{array}{l}\text { Perceived capabili- } \\
\text { ties }\end{array}$ & CAP & $\begin{array}{l}\text { Perceived capabilities (Percentage of } 18-64 \text { year- } \\
\text { old population who believe they have the required } \\
\text { skills and knowledge to start a business) }\end{array}$ & GEM \\
\hline \multirow[t]{11}{*}{$\begin{array}{l}\text { Institutional and } \\
\text { financial factors }\end{array}$} & FIN & $\begin{array}{l}\text { Financing for entrepreneurs (The availability of } \\
\text { financial resources -equity and debt- for small and } \\
\text { medium enterprises (SMEs). Including grants and } \\
\text { subsidies) }\end{array}$ & GEM \\
\hline & INTER & Central bank interest rate $(\%)$ & Datosmacro $^{\mathrm{b}}$ \\
\hline & TAXB & $\begin{array}{l}\text { Taxes and bureaucracy (The extent to which public } \\
\text { policies support entrepreneurship - taxes or regu- } \\
\text { lations are either size-neutral or encourage new } \\
\text { and SMEs) }\end{array}$ & GEM \\
\hline & TAX & Tax Burden & \multirow[t]{8}{*}{$\mathrm{IEF}^{\mathrm{c}}$} \\
\hline & GOVSP & Government Spending & \\
\hline & GOVINT & Government Integrity & \\
\hline & $\mathrm{BF}$ & Business Freedom & \\
\hline & $\mathrm{LF}$ & Labour Freedom & \\
\hline & $\mathrm{TF}$ & Trade Freedom & \\
\hline & MF & Monetary Freedom & \\
\hline & IF & Investment Freedom & \\
\hline
\end{tabular}


Table 1 (continued)

\begin{tabular}{|c|c|c|c|}
\hline $\begin{array}{l}\text { Socio-economic } \\
\text { explanatory factor }\end{array}$ & $\begin{array}{l}\text { Proxy vari- } \\
\text { able }\end{array}$ & Concept & Database \\
\hline & $\mathrm{FF}$ & Financial Freedom & \\
\hline & POL & $\begin{array}{l}\text { Governmental support and policies (The extent to } \\
\text { which public policies support entrepreneurship- } \\
\text { entrepreneurship as a relevant economic issue) }\end{array}$ & GEM \\
\hline $\begin{array}{l}\text { Country's level of } \\
\text { development }\end{array}$ & GDP & $\begin{array}{l}\text { Gross Domestic Product at absolute values (US\$ } \\
\text { current prices) }\end{array}$ & World Bank \\
\hline
\end{tabular}

${ }^{a}$ OECD iLibrary is the online library of the Organisation for Economic Cooperation and Development (OECD) featuring its books, papers and statistics and is the gateway to OECD's analysis and data (OECD, 2020)

${ }^{b}$ Datamacro aims to offer the main economic and socio-demographic variables of hundreds of countries, to offer a global vision of the economic situation at all times and in each country (Datosmacro. com, 2020)

${ }^{\mathrm{c}}$ The Index of Economic Freedom (IEF) is an annual guide published by The Heritage Foundation. The Index of Economic Freedom documents the positive relationship between economic freedom and a variety of positive social and economic goals. The ideals of economic freedom are strongly associated with healthier societies, cleaner environments, greater per capita wealth, human development, democracy, and poverty elimination. The Index covers 12 freedoms - from property rights to financial freedom - in 186 countries. For this study, the factors most representative of entrepreneurship were selected (Index of Economic Freedom, 2020)

by using GDP at absolute values). These findings will be useful for the formulation and implementation of effective public policies that promote female entrepreneurship.

Models 1, 2 and 3 were designed to consider the relative importance depending on the country's level of development. Model 1 (M1) was proposed for all countries, Model 2 (M2) was proposed for higher development countries (their GDP is above the total average GDP for the group), and Model 3 (M3) was proposed for lower development countries (their GDP is above the total average GDP for the group) (see Table 4).

These models shows that all relationships among variables are significant, ( $p$-values: ${ }^{*} p \leq 10$ per cent; ${ }^{* *} p \leq 5$ per cent; ${ }^{* * *} p \leq 1$ per cent) and, therefore, it is valid

Table 2 Countries considered for each exploratory model (2001-2018)

\begin{tabular}{ll}
\hline Classification & Countries
\end{tabular}

Total UE

Higher development (above the total average GDP)

Lower development (below the total average GDP)
Austria, Croatia, Finland, France, Germany, Greece, Hungary, Ireland, Italy, Luxembourg, Netherlands, Poland, Portugal, Russia, Slovakia, Slovenia, Spain, Sweden, Switzerland, United Kingdom

France, Germany, Italy, Russia, Spain, United Kingdom

Austria, Finland, Greece, Hungary, Ireland, Luxembourg, Netherlands, Poland, Portugal, Slovakia, Slovenia, Sweden, Switzerland 
Table 3 Exploratory econometric models estimated

\begin{tabular}{|c|c|c|c|}
\hline & $\begin{array}{l}\text { Total } \\
\text { ( } 20 \text { countries })\end{array}$ & $\begin{array}{l}\text { Higher develop- } \\
\text { ment } \\
\text { ( } 6 \text { countries })\end{array}$ & $\begin{array}{l}\text { Lower develop- } \\
\text { ment } \\
\text { (13 countries) }\end{array}$ \\
\hline $\begin{array}{l}\text { Dependent variable: TEA } \\
\text { Independent variables: FNTEA, FOTEA }\end{array}$ & M1 & M2 & M3 \\
\hline $\begin{array}{l}\text { Dependent variable: FTEA } \\
\text { Independent variables: socio-economic } \\
\text { explanatory factors }\end{array}$ & M4, M5 & M6, M7 & M8, M9 \\
\hline $\begin{array}{l}\text { Dependent variable: FNTEA } \\
\text { Independent variables: socio-economic } \\
\text { explanatory factors }\end{array}$ & M10, M11 & M12, M13 & M14, M15 \\
\hline
\end{tabular}

$(p \leq 0.01)$ to study and analyze TEA through the two main FTEA components considered, both through necessity and opportunity. In most settings, researchers choose a significance level of 5 per cent, which implies that the p-values must be lower than 0.05 in order to render the relationship under consideration significant. When researchers are very conservative or strict in their testing of relationships, the significance level is set to 1 per cent. In studies that are exploratory, however, a significance level of 10 per cent is commonly used (Hair et al., 2016, p. 153).

However, both motivations do not explain to the same extent the behaviour of the total entrepreneurial activity since results suggest that more women enter into entrepreneurship due to necessity rather than pursuit of opportunity in all countries considered $\quad\left(\beta_{F N T E A / T E A}^{*}=0.5275>\beta_{\text {FOTEA } / T E A}^{*}=0.0594 ; \quad \beta_{F N T E A / T E A}^{*}=1.6909>\beta\right.$ $\left.{ }_{\text {FOTEA } / \text { TEA }}^{*}=0.1092 ; \beta_{\text {FNTEA } / T E A}^{*}=1.5735>\beta_{\text {FOTEA } / T E A}^{*}=0.0623\right)$. Therefore, $\mathrm{H} 1$ is not supported.

Table 4 Exploratory explanatory models of TEA by FNTEA and FOTEA component. All countries, higher development countries and lower development countries

\begin{tabular}{llll}
\hline Dependent variable: TEA & $\begin{array}{l}\text { M1 } \\
\text { (all countries) }\end{array}$ & $\begin{array}{l}\text { M2 } \\
\text { (higher development) }\end{array}$ & $\begin{array}{l}\text { M3 } \\
\text { (lower development) }\end{array}$ \\
\hline $\begin{array}{l}\text { Independent variables } \\
\text { (significant and uncorrelated) }\end{array}$ & $\begin{array}{l}\text { FNTEA }(+) * * * \\
\text { FOTEA }(+) *\end{array}$ & $\begin{array}{l}\text { FNTEA }(+) * * * \\
\text { FOTEA }(+) *\end{array}$ & $\begin{array}{l}\text { FNTEA }(+) * * * \\
\text { FOTEA }(+) *\end{array}$ \\
& FNTEA: 1.4614 & FNTEA: 1.6941 & FNTEA: 1.5735 \\
Ftandardized coefficientsa $\left(\beta^{*}\right)$ & FNTEA: 0.5275 & FNTEA: 1.6909 & FOTEA: 1.1639 \\
& FOTEA: 0.0594 & FOTEA: 0.1092 & FNTEA: 1.5735 \\
R2-adjusted & 0.8071 & 0.7620 & 0.7865 \\
Estimation $($ Hausman Test)b & FE & FE & FE \\
$\mathrm{N}$ (groups) & $108(20$ groups $)$ & $33(6$ groups $)$ & $56(11$ groups $)$ \\
\hline
\end{tabular}

$p$-value $* p \leq 0.10 ; * * p \leq 0.5 ; * * * p \leq 0.01$

${ }^{a}$ The standardized coefficients obtained in the six models are not an output of Stata software. The standardized coefficients have been calculated directly from the unstandardized coefficients along with the standard deviations of the variables involved: $\beta_{j}^{*}=\hat{\beta}_{j} *\left(\frac{S D x_{j}}{S D y_{j}}\right)$

${ }^{\mathrm{b}}$ The Hausman test was used to determine the most appropriate estimation method - fixed effects (FE) or random effects $(\mathrm{RE})$ - in order to obtain the most robust parameters in each case 
Table 5 Explanatory exploratory models of FTEA by socio-economic explanatory factors (all countries)

\begin{tabular}{lll}
\hline Dependent variable: FTEA & $\begin{array}{l}\text { M4 } \\
\text { (all countries) }\end{array}$ & $\begin{array}{l}\text { M5 } \\
\text { (all countries) }\end{array}$ \\
\hline $\begin{array}{l}\text { Independent variables } \\
\text { (significant and uncorrelated) }\end{array}$ & $\begin{array}{l}\text { TEA }(+) * * * \\
\text { TEDT }(-) * *\end{array}$ & $\begin{array}{l}\text { MTEA }(+) * * * \\
\text { FNTEA }(+) * * *\end{array}$ \\
Coefficients & INTER $(-) * * *$ & CAP $(-) * *$ \\
& TEA: 0.3629 & MTEA: 0.2729 \\
& TEDT: $-5.17 \mathrm{E}-09$ & FNTEA: 0.5511 \\
Standardized coefficients $\left(\beta^{*}\right)$ & INTER: -0.0341 & CAP: -0.0129 \\
& TEA: 0,9134 & MTEA: 0.4556 \\
R2-adjusted & TEDT: $-0,0757$ & FNTEA: 0.5007 \\
Estimation (Hausman Test) & INTER: $-0,1021$ & CAP: -0.1266 \\
$\mathrm{~N}$ (groups) & 0.8225 & 0.7868 \\
\hline
\end{tabular}

$p$-value $* p \leq 0.10 ; * * p \leq 0.5 ; * * * p \leq 0.01$

Next, exploratory models of the behaviour of FTEA were proposed (see Tables 5, $6,7)$. As in the previous case, the effect of the country's level of development (measured by using GDP at absolute values) -all countries (see Table 5, M4 y M5), higher development countries (Table 6, M6 y M7) and lower development countries (see Table 7, M8 y M9)—was analyzed. These models were estimated to explain the behaviour of FTEA, thus socio-economic explanatory factors (human capital, perceived capabilities, institutional and financial factors) were also considered.

These models suggest that it is valid $(p \leq 0.01)$ to study and analyze FTEA through socio-economic explanatory factors. Once again (as in M1 to M3) the results shows that more women enter into entrepreneurship due to necessity (FNTEA)

Table 6 Explanatory exploratory models of FTEA by socio-economic explanatory factors (higher development countries)

\begin{tabular}{lll}
\hline Dependent variable: FTEA & $\begin{array}{l}\text { M6 } \\
\text { (higher development) }\end{array}$ & $\begin{array}{l}\text { M7 } \\
\text { (higher development) }\end{array}$ \\
\hline $\begin{array}{lll}\text { Independent variables } \\
\text { (significant and uncorrelated) }\end{array}$ & TEA $(+)^{* * *}$ & MTEA $(+) * * *$ \\
& TEDF $(-)^{*}$ & LF $(+)^{*}$ \\
Coefficients & INTER $(-)^{*}$ & MTEA: 0.4306 \\
& TEA: 0.4041 & LF: -0.0108 \\
TED: $-4.44 \mathrm{E}-09$ & CAP: 0.1331 \\
& INTER: -0.0308 & MTEA: 0.6666 \\
& TEA: 0.9443 & LABF: -0.1880 \\
R2-adjusted & TEDF: -0.0845 & CAP: 2.0030 \\
Estimation (Hausman Test) & INTER: -0.1354 & 0.5342 \\
$\mathrm{~N}$ (groups) & 0.7858 & FE \\
\hline
\end{tabular}

$p$-value $* p \leq 0.10 ; * * p \leq 0.5 ; * * * p \leq 0.01$ 
Table 7 Explanatory exploratory models of FTEA by socio-economic explanatory factors (lower development countries)

\begin{tabular}{lll}
\hline Dependent variable: FTEA & $\begin{array}{l}\text { M8 } \\
\text { (lower development) }\end{array}$ & $\begin{array}{l}\text { M9 } \\
\text { (lower development) }\end{array}$ \\
\hline $\begin{array}{l}\text { Independent variables } \\
\text { (significant and uncorrelated) }\end{array}$ & $\begin{array}{l}\text { TEA }(+) * * * \\
\text { TEDT }(-) * * *\end{array}$ & $\begin{array}{l}\text { MTEA }(+) * * * \\
\text { FNTEA }(+) * * *\end{array}$ \\
Coefficients & INTER $(-) * * *$ & CAP (-) *** \\
& TEA: 0.3527399 & MTEA: 0.2439 \\
Standardized coefficients $\left(\beta^{*}\right)$ & TEDT: $-7.07 E-09$ & FNTEA: 0.6469 \\
& INTER: -0.0398 & CAP: -0.0241 \\
R2-adjusted & TEA: 0.9236 & MTEA: 0.4614 \\
Estimation (Hausman Test) & TEDT: -0.0939 & FNTEA: 0.6521 \\
$\mathrm{~N}$ (groups) & INTER: -0.0398 & CAP: -0.2060 \\
\hline
\end{tabular}

$p$-value $* p \leq 0.10 ; * * \leq 0.5 ; * * * p \leq 0.01$

rather than pursuit of opportunity in all European countries considered. The R2 of M7 was small. This is because many other factors also influence the opportunity and necessity entrepreneur variables.

The level of education does not have a positive impact on female entrepreneurship for any country considered. Women with higher levels of human capital will prefer the security of a salaried job according to their qualifications with good conditions (Millán et al., 2014), against the risk and uncertainty associated with self-employment (Galindo-Martin et al., 2010; Valliere \& Peterson, 2009; van Der Sluis et al., 2008). Conversely, financing dependent on interest rates is a determining factor for female entrepreneurship in the three groups of countries considered. Additionally, the value of the standardized coefficients obtained makes it possible to conclude that financial factors explain FTEA behaviour to a greater extent than human capital for all the groups of countries considered (M4: $\beta_{\text {INTER/FTEA }}^{*}=1$ $-0.1021\left|>\beta_{\text {TEDT } / F T E A}^{*}=\right|-0.0757\left|; M 4: \beta_{\text {INTER } / F T E A}^{*}=\right|-0.1021 \mid>\beta_{\text {TEDT } / F T E A}^{*}$ $=|-0.0757|$ M6: $\beta_{\text {INTER } / F T E A}^{*}=|-0.1354|>\beta_{\text {TEDF } / F T E A}^{*}=|-0.0845| ; \quad$ M8: $\beta_{\text {INTER } /}$ $/ F T E A^{*}=|-0.0398|>\beta_{\text {TEDT } / F T E A}^{*}=-7.07 E-09 M 6: \beta_{\text {INTER } / F T E A}^{*}=|-0.1354|>$ $\beta_{\text {TEDT } / F T E A}^{*}=|-0.0845| \quad M 8: \beta_{\text {INTER } / F T E A}^{*}=|-0.0398|>\beta_{\text {TEDT } / F T E A}^{*}=-7.07 E-$ 09).

Perceived capabilities (CAP) positively affect FTEA in higher development countries (with higher GDP levels) but not in lower development (with lower GDP levels) countries. The woman will put her self-perceived knowledge and skills into practice if the economic environment is favourable. Otherwise, in countries with a lower level of development, they are more likely to be employed by public or private organizations.

Finally, considering that more women enter into entrepreneurship due to necessity rather than pursuit of opportunity in all countries considered, exploratory models of the behaviour of FNTEA were proposed (Tables 8, 9, 10). As in the previous case, 
Table 8 Explanatory exploratory models of FNTEA by socio-economic explanatory factors (all countries)

\begin{tabular}{lll}
\hline Dependent variable: FNTEA & $\begin{array}{l}\text { M10 } \\
\text { (all countries) }\end{array}$ & $\begin{array}{l}\text { M11 } \\
\text { (all countries) }\end{array}$ \\
\hline $\begin{array}{l}\text { Independent variables } \\
\text { (significant and uncorrelated) }\end{array}$ & $\begin{array}{l}\text { MTEA }(+)^{* * *} \\
\text { TEDF }(-) * * *\end{array}$ & $\begin{array}{l}\text { MTEA }(+) * * * \\
\text { TEDT }(-) * * *\end{array}$ \\
Coefficients & PIB $(-) *$ & INTER $(+)^{* * *}$ \\
& MTEA: 0.3743 & MTEA: 0.3979 \\
& TEDF: $-9.55 E-09$ & TEDT: $-9.35 E-09$ \\
Standardized coefficients $\left(\beta^{*}\right)$ & PIB: $-1.57 \mathrm{E}-13$ & INTER: 0.0720 \\
& MTEA: 0.6825 & MTEA: 0.7314 \\
& TEDF: -0.1529 & TEDT: -0.1507 \\
R2-adjusted & PIB: -0.1984 & INTER: 0.2374 \\
Estimation (Hausman Test) & 0.5162 & 0.5040 \\
$\mathrm{~N}$ (groups) & FE & FE \\
\hline
\end{tabular}

$p$-value $* p \leq 0.10 ; * * \leq 0.5 ; * * * p \leq 0.01$

the effect of the country's level of development (measured by using GDP at absolute values) -all countries (Table 8, M10 y M11), higher development countries (higher levels of GDP) (Table 9, M12 y M13) and lower development countries (lower levels of GDP) (Table 10, M14 y M15)—was analyzed. These models were estimated to explain the behaviour of FNTEA, thus socio-economic explanatory factors (human capital, perceived capabilities, institutional and financial factors) were also considered.

They show that that FNTEA behavior is influenced by similar factors in all 20 countries considered. Therefore, significant differences are not observed between the explanatory factors of FNTEA depending on their level of GDP, except for the perceived capabilities (CAP). Therefore, H2 can be partially accepted. R2-adjusted of M10 to M15 were small. This is because many other factors also influence the necessity entrepreneur variables.

Table 9 Explanatory exploratory models of FNTEA by socio-economic explanatory factors (higher development countries)

\begin{tabular}{lll}
\hline Dependent variable: FNTEA & $\begin{array}{l}\text { M12 } \\
\text { (higher development) }\end{array}$ & $\begin{array}{l}\text { M13 } \\
\text { (higher development) }\end{array}$ \\
\hline $\begin{array}{l}\text { Independent variables } \\
\text { (significant and uncorrelated) }\end{array}$ & $\begin{array}{l}\text { MTEA }(+)^{* * *} \\
\text { TEDF }(-) *\end{array}$ & $\begin{array}{l}\text { MTEA }(+) * * * \\
\text { TRAP }(+)^{*}\end{array}$ \\
Coefficients & MTEA: 0.3963 & MONF $(-) *$ \\
& TEDF: $-9.38 E-09$ & MTEA: 0.2458 \\
Ttandardized coefficients $\left(\beta^{*}\right)$ & TF: -0.0442 & CAP: 0.0227 \\
& MTEA: 0.5746 & MONF: -0.0339 \\
R2-adjusted & TEDF: -0.1671 & MTEA: 0.3564 \\
Estimation (Hausman Test) & TRADF: -0.5464 & CAP: 0.3193 \\
$\mathrm{~N}$ (groups) & 0.3338 & MONF: -0.4468 \\
\hline
\end{tabular}

$p$-value $* p \leq 0.10 ; * * p \leq 0.5 ; * * * p \leq 0.01$ 
Table 10 Explanatory exploratory models of FNTEA by socio-economic explanatory factors (lower development countries)

\begin{tabular}{lll}
\hline Dependent variable: FNTEA & $\begin{array}{l}\text { M14 } \\
\text { (lower development) }\end{array}$ & $\begin{array}{l}\text { M15 } \\
\text { (lower development) }\end{array}$ \\
\hline $\begin{array}{l}\text { Independent variables } \\
\text { (significant and uncorrelated) }\end{array}$ & $\begin{array}{l}\text { MTEA }(+) * * * \\
\text { TEDF }(-) *\end{array}$ & $\begin{array}{l}\text { MTEA }(+) * * * \\
\text { TEDT }(-) * *\end{array}$ \\
Coefficients & GOVSP $(+) *$ & INTER $(+) * * *$ \\
& MTEA: 0.3471 & MTEA: 0.3919 \\
Standardized coefficients $\left(\beta^{*}\right)$ & TEDF: $-7.80 E-09$ & TEDT: $-1.00 E-08$ \\
& GOVSP: 0.0050 & INTER: 0.0604 \\
R2-adjusted & MTEA: 0.6513 & MTEA: 0.7352 \\
Estimation (Hausman Test) & TEDF: -0.1285 & TEDT: -0.1318 \\
$\mathrm{~N}$ (groups) & GOVSP: 0.1125 & INTER: 0.2270 \\
\hline
\end{tabular}

$p$-value $* p \leq 0.10 ; * * p \leq 0.5 ; * * * p \leq 0.01$

First, high levels of human capital (TEDF, TEDT) do not have a positive effect on FNTEA for any group of countries considered (just as for the FTEA case in M4, M6 and M8) because higher levels of education increase well-paid employment opportunities. However, the perceived capabilities (CAP) positively affect FNTEA in higher development countries (higher levels of GDP) but not in lower development countries (lower levels of GDP) (as in the case of FTEA in M7).

Secondly, these models suggest that institutional and financial factors exert a significant influence on the behaviour of FNTEA. Furthermore, financial factors explain FNTEA behaviour to a greater extent than human capital in lower development countries (M15: $\left.\beta_{\text {INTER/FNTEA }}^{*}=0.2270>\beta_{\text {TEDT } / F N T E A}^{*}=|-0.1318|\right)$ and CAP in higher development countries (M13: $\beta_{M O N F / F N T E A}^{*}=|-0.4468|>\beta_{C A P /}$ FNTEA $^{*}=0.3193$ ).

Thirdly, the direct relationship between FNTEA and MTEA may be due to the fact that, as discussed above, men are in a better position to take advantage of all the business opportunities, forcing women to become entrepreneurs out of necessity.

Table 11 summarises the empirical results. All the explanatory factors of female entrepreneurship are shown. The explanatory factors of FNTEA which can be apply as the most efficient policy instruments to promote FNTEA have been highlighted with asterisk (*) for each group of countries. Two selection criteria have been applied for selecting them. Firstly, the higher the absolute value of the standardized beta coefficient $\left(\beta^{*}\right)$, the stronger the effect on dependent variable (FNTEA). Secondly, variables should have signs consistent with economic theory.

The following findings can be drawn from each one of these final econometric models (M1 to M15).

Firstly, models M1 to M3 show that more women enter into entrepreneurship due to necessity (FNTEA) rather than pursuit of opportunity in all European 
Table 11 Explanatory factors of female entrepreneurship by group of EU countries

\begin{tabular}{|c|c|c|c|}
\hline \multirow[b]{2}{*}{ Dependent variable } & \multicolumn{3}{|l|}{ Explanatory factors } \\
\hline & All countries & Higher development (GDP) & Lower development (GDP) \\
\hline $\begin{array}{l}\text { TEA } \\
\text { (M1 to M3) }\end{array}$ & $\begin{array}{l}\text { - }(\mathrm{M} 1) \text { FNTEA }(*) \\
\text { - FOTEA }\end{array}$ & $\begin{array}{l}\text { - }(\mathrm{M} 2) \text { FNTEA }(*) \\
\text { - FOTEA }\end{array}$ & $\begin{array}{l}\text { - }(\mathrm{M} 3) \text { FNTEA }(*) \\
\text { - FOTEA }\end{array}$ \\
\hline $\begin{array}{l}\text { FTEA } \\
\text { (M4 to M9) }\end{array}$ & $\begin{array}{l}\text { - TEA } \\
\text { - MTEA } \\
\text { - FNTEA } \\
\text { - Human capital } \\
\text { - Financial factor } \\
\text { - Perceived Capabilities }\end{array}$ & $\begin{array}{l}\text { - TEA } \\
\text { - MTEA } \\
\text { - Human capital } \\
\text { - Institutional factors } \\
\text { - Financial factors } \\
\text { - Perceived Capabilities }\end{array}$ & $\begin{array}{l}\text { - TEA } \\
\text { - MTEA } \\
\text { - FNTEA } \\
\text { - Human capital } \\
\text { - Financial factors } \\
\text { - Perceived Capabilities }\end{array}$ \\
\hline $\begin{array}{l}\text { FNTEA } \\
\text { (M10 to M15) }\end{array}$ & $\begin{array}{l}\text { - MTEA } \\
\text { - PIB } \\
\text { - Human capital } \\
\text { - }(\text { M11) Financial fac- } \\
\quad \text { tors }(\text { INTER) }(*)\end{array}$ & $\begin{array}{l}\text { - MTEA } \\
\text { - Human capital } \\
\text { - Institutional factors } \\
\text { - Financial factors } \\
\text { - }(\text { M13) Perceived Capa- } \\
\text { bilities (CAP) }(*)\end{array}$ & $\begin{array}{l}\text { - MTEA } \\
\text { - Human capital } \\
\text { - }(\text { M15) Institutional fac- } \\
\quad \text { tors }(\text { GOVSP) }(*) \\
-(\text { M15) Financial factors } \\
\quad(\text { INTER })(*)\end{array}$ \\
\hline
\end{tabular}

(*) Instrumental variables with the strongest effect on dependent variable

countries considered. Thus, exploratory models of the behaviour of FNTEA must be considered in order to implement more efficient public policies to promote it.

Secondly, models M4 to M9 show that female total entrepreneurial activity (FTEA) is naturally driven by total entrepreneurial activity (TEA) and by male entrepreneurial activity (MTEA). However, FTEA is also driven by other specific factors that will be used to design efficient and effective policies to promote FTEA (as will be shown in the next section). For instance, "perceived capabilities" (CAP) stimulate the FTEA for higher development countries (higher GDP average), while the opposite situation exists for lower development countries (lower GDP average). For this reason, H2 have been partially accepted.

Finally, models M10 to M15 inform how to implement efficient policy to promote FNTEA for each group of countries. In addition to identify the explanatory factors on those policies can't be implemented (i.e., MTEA and PIB), the following are worth noting. Perceived capabilities (CAP) positively affect FNTEA in higher development countries (with higher GDP levels) and FNTEA can be promoted by rises in interest rates (INTER) and rises in government spending (GOVSP) in lower development countries (with lower GDP levels). All in all, perceived capacities, interest rates and government spending should be considered in order to implement efficient policies to promote female entrepreneurship in Europe.

\section{Conclusions and policy implications}

Nowadays, women entrepreneurs have become part of the important factor in the world of entrepreneurship and they are recognised as key contributors to economic growth. Thus, her activity has attracted the attention of researchers and policy makers alike (Alsos et al., 2016; Shmailan, 2016; Brush et al., 2020). 
This paper has explored and examined the behaviour of female entrepreneurial activity in 20 European developed countries, considering two main types of entrepreneurship (necessity and opportunity). To do this, it defined the explanatory factors that determine this behaviour, as well as the relative importance of these factors at different levels of economic development (measured by using GDP at absolute values). The results of the empirical analysis do not offered support for the hypothesis $\mathrm{H} 1$, and $\mathrm{H} 2$ was counted as being partially supported.

The rate of total entrepreneurial activity (TEA) was shown to be sufficiently and very well represented by two of the components of female entrepreneurship, i.e., opportunity-driven, and necessity-driven entrepreneurship (FOTEA and FNTEA, respectively). This finding is consistent with the opinion of scholars who argue that women can improve the level of entrepreneurial activities in a country (Sarfaraz et al., 2014). Additionally, the value of the standardized coefficients obtained makes it possible to conclude that FNTEA explains TEA behaviour to a greater extent than FOTEA in the three groups of countries considered (H1 was not supported) (M1 to M3). These results show that more women enter into entrepreneurship due to necessity rather than in pursuit of opportunity, but the most surprising finding was that contrary to related research on the subject so far (Fairlie \& Fossen, 2018; Amorós et al., 2019), most women in developed countries with high levels of GDP engage in necessity-based entrepreneurship. For this reason, to design and implement effective policies to promote women entrepreneurship in Europe, factors influencing necessity-based female entrepreneurship (FNTEA) should be considered.

Significant differences were not observed between the explanatory factors of FNTEA depending on their level of GDP. The only exception is for the "perceived capabilities" (CAP) (H2 was partially accepted) that positively affect FNTEA in higher development countries (with higher GDP levels) (M13) but not in lower development countries (with lower GDP levels). This finding will facilitate the implementation of effective common policies in Europe to promote female entrepreneurship.

In light of the consistency between theory and practice, the analytical technique used here can be considered adequate.

These findings have the following policy implications for promoting female entrepreneurship in Europe (Fig. 2).

In lower development countries (with lower GDP levels) the following policy measures should be implemented to promote FNTEA. On the one hand, the quality of governance should be improved, for example, by optimizing government spending (GOVSP). Following the European Commission policy recommendations (OECD, 2017), policy makers can support female entrepreneurs by offering training courses and mentoring and ensuring that their policies help women to participate in the labour market. The public procurement could be another important programme to open up market opportunities for women and providing more support for growth-oriented women entrepreneurs with dedicated business incubator and business accelerator programmes and the creation of an infrastructure for risk capital. In this context, the Entrepreneurship 2020 Action Plan calls for awareness raising, entrepreneurship training, stronger networks and support in reconciling business and family life (European Commission, 2020a). This is particularly important now in relation to the Covid-19 pandemic. 


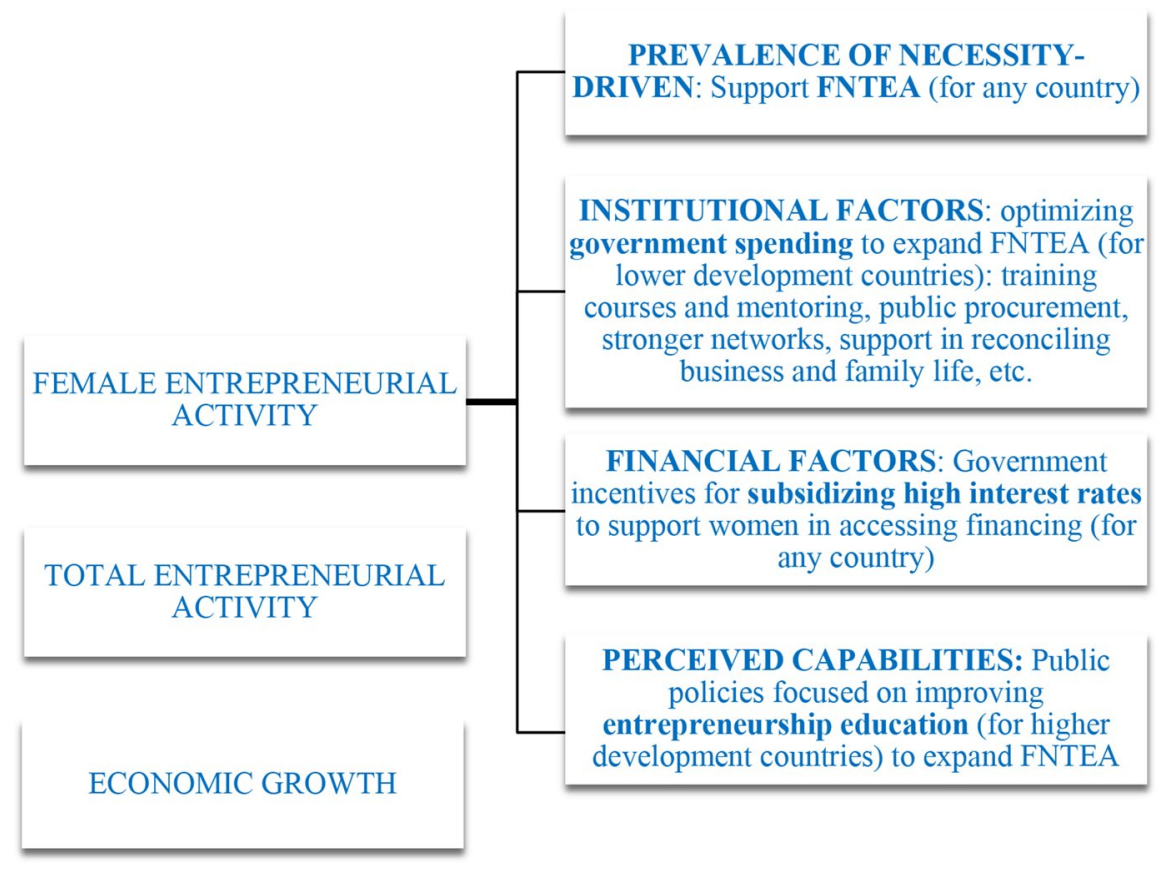

Fig. 2 Summary of results obtained: drivers of female entrepreneurship

On the other hand, interest rates increase can be a response of Central banks when the economy is overly strong. The higher the level of economic activity rate of growth, the greater the women possibilities for starting a business. However, the main obstacle for investment will be the higher cost of bank financing. The solution to overcome this problem could be government incentives for subsidizing high interest rates. Fortunately, there is a growing trend in public policy to offer more substantial tailored financial supports for women entrepreneurs (OECD, 2017, p.21). For instance, the Commission is launching a gender-smart finance initiative under the InvestEU programme, to stimulate funding for female-led companies and funds (European Commission, 2020a). Likewise, there are a number of public policy instruments used in EU Member States to improve access to finance for women entrepreneurs: grants, microcredits, crowdfunding and public procurement opportunities, etc. (OECD, 2017).

Finally, in higher development countries (with higher GDP levels) perceived capabilities (CAP) positively affect FNTEA. This finding is consistent with the fact that one of the most important features of entrepreneurship is entrepreneurs' recognition that they possess the knowledge and skills needed to start a business (Peña et al., 2015). Accordingly, the implementation of public policies focused on improving entrepreneurial education could be a good measure to promote FNTEA in higher development countries. This is corroborated by the European Commission (2020b) as one of its main objectives is to promote education in this field and stress its importance at all levels from primary school to university and beyond. Likewise, 
The Commission has encouraged initiatives that help women build confidence in their remarkable abilities (European Commission, 2020b).

\section{Limitations and directions for future research}

The empirical work had certain limitations. For instance, the data are not homogeneous due to the lack of statistical information for many of the years and countries considered in the selected databases, especially when the analysis is conducted for multiple countries, as in the present case. When GEM presents the homogenized data without statistical gaps, the resulting conclusions will be more solvent and closer to reality.

Notwithstanding its limitations, the present research opens avenues of future research. First, the empirical analysis aimed at providing an adequate and effective methodology for studying female entrepreneurial activity in terms of the technique used, which is valid for all European countries. Secondly, analyzing female entrepreneurial behaviour by levels, divided into levels of development of the countries (measured by using GDP at absolute values), makes it possible to use the results for decision-making, by designing more effective economic policy measures to achieve the objective of promoting female entrepreneurship and, with it, economic growth. TEA behaviour could thus be further specified. At the same time, given the scant literature to date focused on the impact of factors on necessity- or opportunity-driven female entrepreneurship, future research could seek to overcome this limitation.

Acknowledgments We would like to thank the Faculty of Law and Social Sciences, Ciudad Real, for providing us with valuable support that helped us write this paper.

Author Contributions All authors have contributed equally to this work. All authors have read and agreed to the published version of the manuscript.

Funding This research received no external funding.

Declarations

Conflicts of Interest The funders had no role in the design of the study; in the collection, analyses, or interpretation of data; in the writing of the manuscript, or in the decision to publish the results.

\section{References}

Acs, Z. J. (2006). How is entrepreneurship good for economic growth? Innovations, 1(1), 97-107.

Allen, I. E., Elam, A., Langowitz, N., \& Dean, M. (2008). Report on Women and Entrepreneurship. Global Entrepreneur Monitor (GERA).

Alsos, G. A., \& Ljunggren, E. (2017). The Role of Gender in Entrepreneur-Investor Relationships: A Signaling Theory Approach: Entrepreneurship Theory and Practice, https://doi.org/10.1111/etp. 12226 
Alsos, G. A., Ljunggren, E., Carter, S., \& Jørstad, M. (2016). Women, Family and Entrepreneurship: Strategies for Managing Work-Life Balance Challenges. Academy of Management Proceedings, https://doi.org/10.5465/AMBPP.2016.16079abstract

Álvarez, C., Noguera, M., \& Urbano, D. (2012). Condicionantes del entorno y emprendimiento femenino: un estudio cuantitativo en España. Economía industrial, 383, 43-52.

Amorós, J. E., \& Guerra, M. (2009). Global Entrepreneurship Monitor: Reporte Nacional de Chile, Global Entrepreneur Monitor 2008 National Report, Ediciones Universidad del Desarrollo.

Amorós, J. E., Ciravegna, L., Mandakovic, V., \& Stenholm, P. (2019). Necessity or Opportunity? The Effects of State Fragility and Economic Development on Entrepreneurial Efforts. Entrepreneurship Theory and Practice, 43(4), 725-750.

Antai, A., \& Anam, B. (2016). Gender Disparity in Education, Employment and Access to Productive Resources as Deterrent to Economic Development. Journal of Public Administration and Governance, https://doi.org/10.5296/jpag.v6i3.10090

Anton, S. G., \& Bostan, I. (2017). The Role of Access to Finance in Explaining Cross-National Variation in Entrepreneurial Activity: A Panel Data Approach. Sustainability. https://doi.org/10.3390/su9111947

Åstebro, T., \& Tåg, J. (2017). Gross, net, and new job creation by entrepreneurs. Journal of Business Venturing Insights, 8, 64-70.

Audretsch, D. B. (2007). Entrepreneurship Capital and Economic Growth. Oxford Review of Economic Policy. https://doi.org/10.1093/oxrep/grm001

Barba-Sánchez, V., \& Atienza-Sahuquillo, C. (2018). Entrepreneurial intention among engineering students: The role of entrepreneurship education. European Research on Management and Business Economics, 24(1), 53-61.

Baughn, C. C., Chua, B., \& Neupert, K. E. (2006). The Normative Context for Women's Participation in Entrepreneruship: A Multicountry Study. Entrepreneurship Theory and Practice. https://doi.org/ 10.1111/j.1540-6520.2006.00142.x

Baum, J. A. C., \& Silverman, B. S. (2004). Picking Winners or Building Them? Alliance, Intellectual, and Human Capital as Selection Criteria in Venture Financing and Performance of Biotechnology Startups. Journal of Business Venturing. https://doi.org/10.1016/S0883-9026(03)00038-7

Becker, G. S. (1964). Human Capital: A Theoretical and Empirical Analysis, with Special Reference to Education The University of Chicago Press.

Becker-Blease, J. R., \& Sohl, J. E. (2007). Do Women-Owned Businesses Have Equal Access to Angel Capital? Journal of Business Venturing. https://doi.org/10.1016/j.jbusvent.2006.06.003

Bigelow, L., Lundmark, L., McLean Parks, J., \& Wuebker, R. (2014). Skirting the Issues: Experimental Evidence of Gender Bias in IPO Prospectus Evaluations. Journal of Management. https://doi.org/ $10.1177 / 0149206312441624$

Block, J. H., \& Wagner, M. (2010). Necessity and Opportunity Entrepreneurs in Germany: Characteristics and Earning s Differentials. Schmalenbach Business Review. https://doi.org/10.1007/BF03396803

Brush, C., Ali, A., Kelley, D., \& Greene, P. (2017). The influence of human capital factors and context on women's entrepreneurship: Which matters more? Journal of Business Venturing Insights, 8, $105-113$.

Brush, C., Greene, P., \& Welter, F. (2020). The Diana project: a legacy for research on gender in entrepreneurship. International Journal of Gender and Entrepreneurship. https://doi.org/10.1108/ IJGE-04-2019-0083

Cabrera, E. M., \& Mauricio, D. (2017). Factors affecting the success of women's entrepreneurship: a review of literature. International Journal of Gender and Entrepreneurship. https://doi.org/10. 1108/IJGE-01-2016-0001

Carsrud, A., \& Brännback, M. (2010). Entrepreneurial Motivations: What Do We Still Need to Know? Journal of Small Business Management, 49(1), 9-26.

Carter, N. M., Gartner, W. B., Shaver, K. G., \& Gatewood, E. J. (2003). The Career Reasons of Nascent Entrepreneurs. Journal of Business Venturing. https://doi.org/10.1016/S0883-9026(02)00078-2

Carter, S. (1993). Female Business Ownership: Current Research and Possibilities for the Future. In S. Allen \& C. Truman (Eds.), Woman in Bussiness, Perspectives on Women Entrepreneurs. (pp. 148160). Rouletge.

Carter, S., Shaw, E., Lam, W., \& Wilson, F. (2007). Gender, Entrepreneurship, and Bank Lending: The Criteria and Processes Used by Bank Loan Officers in Assessing Applications. Entrepreneurship Theory and Practice. https://doi.org/10.1111/j.1540-6520.2007.00181.x

Carter, S., Shaw, E., Wilson, F., \& Lam, W. (2006). Gender, Entrepreneurship and Business Finance: Investigating the Relationship between Banks and Entrepreneurs in the UK. In Growth-oriented Women 
Entrepreneurs and their Businesses, Brush, C., Carter, N., Gatewood, E., Greene, P., Hart, M., Eds., Edward Elgar Publishing: Cheltenham, UK, pp 373-391. https://doi.org/10.4337/9781845429942. 00022

Coleman, S. (2000). Access to Capital and Terms of Credit: A Comparison of Men- and Women-Owned Small Businesses. Journal of Small Business Management, 38(3), 37-52.

Constantinidis, C., Cornet, A., \& Asandei, S. (2006). Financing of Women-Owned Ventures: The Impact of Gender and Other Owner -and Firm-Related Variables. Venture Capital. https://doi.org/10.1080/ 13691060600572557

Cooper, A. C., Woo, C. Y., \& Dunkelberg, W. C. (1988). Entrepreneurs' Perceived Chances for Success. Journal of Business Venturing. https://doi.org/10.1016/0883-9026(88)90020-1

Cuervo, Á., Ribeiro, D., \& Roig, S. (2007). Entrepreneurship: Concepts, Theory and Perspective. Introduction. In Entrepreneurship: Concepts, Theory and Perspective, Cuervo, Á., Ribeiro, D., Roig, S., Eds., Springer: Berlin, Heidelberg, 2007, pp 1-20.

Datosmacro.com. (2020). https://datosmacro.expansion.com/. Accessed 24 July 2020.

DeTienne, D. R., \& Chandler, G. N. (2007). The Role of Gender in Opportunity Identification. Entrepreneurship Theory and Practice. https://doi.org/10.1111/j.1540-6520.2007.00178.x

Doran, J., McCarthy, N., \& O’Connor, M. (2016). Entrepreneurship and Employment Growth across European Regions. Regional Studies, Regional Science, 3(1), 121-128.

Doran, J., McCarthy, N., O'Connor, M., \& Nsiah, C. (2018). The role of entrepreneurship in stimulating economic growth in developed and developing countries. Cogent Economics \& Finance, 6(1), $1-14$.

Eddleston, K., Ladge, J., Mitteness, C., \& Balachandra, L. (2016). Do You See What I See? Signaling Effects of Gender and Firm Characteristics on Financing Entrepreneurial Ventures. Entrepreneurship Theory and Practice, 40(3), 489-514.

Estrin, S., \& Mickiewicz, T. (2011). Institutions and Female Entrepreneurship. Small Business Economics. https://doi.org/10.1007/s11187-011-9373-0

European Commission. (2020a). Entrepreneurship 2020 Action Plan, available at: https://ec.europa.eu/ growth/smes/supporting-entrepreneurship/women-entrepreneurs_en

European Commission. (2020b). Supporting entrepreneurship Commission's actions on entrepreneurship education https://ec.europa.eu/growth/smes/supporting-entrepreneurship/support/education/commi ssion-actions_en. Accessed 23 Jul 2020.

Fairlie, R., \& Fossen, F. (2018). Opportunity versus Necessity Entrepreneurship: Two Components of Business Creation. CESifo Working Paper Series 6854, Available at SSRN: https://ssrn.com/abstract= 3140340

Galindo-Martin, M. A., Méndez-Picazo, M. T., \& Alfaro-Navarro, J. L. (2010). Entrepreneurship International Entrepreneurship and Management Journal. https://doi.org/10.1007/s11365-010-0142-3

Galindo-Martín, M. A., Méndez-Picazo, M. T., \& Castaño-Martínez, M. S. (2019). The role of innovation and institutions in entrepreneurship and economic growth in two groups of countries. International Journal of Entrepreneurial Behavior \& Research, 26(3).

Galindo-Martin, M. A., \& Méndez-Picazo, M. T. (2014). Entrepreneurship, economic growth, and innovation: Are feedback effects at work? Journal of Business Research. https://doi.org/10.1016/j.jbusres. 2013.11.052

GEM. (2020). Global Entrepreneurship Monitor https://www.gemconsortium.org (accessed Jul 24, 2020).

Goby, V. P., \& Erogul, M. S. (2011). Female Entrepreneurship in the United Arab Emirates: Legislative Encouragements and Cultural Constraints. Women's Studies International Forum. https://doi.org/ 10.1016/j.wsif.2011.04.006

Greene, P. G., Brush, C. G., Hart, M. M., \& Saparito, P. (2001). Patterns of Venture Capital Funding: Is Gender a Factor? Venture Capital. https://doi.org/10.1080/13691060118175

Hair, F. J., Hult, G. T. M., Ringle, C., \& Sarstedt, M. (2016). A Primer on Partial Least Squares Structural Equation Modeling (PLS-SEM) SAGE Publications.

Hajizadeh, A., \& Zali, M. (2016). Prior knowledge, cognitive characteristics and opportunity recognition. International Journal of Entrepreneurial Behavior \& Research, 22(1), 63-83.

Halabisky, D. (2018). Policy Brief on Women's Entrepreneurship. OECD SME and Entrepreneurship Papers., Paris: OECD Publishing.

Hechavarria, D., Bullough, A., Brush, C., \& Edelman, L. (2019). High-Growth Women's Entrepreneurship: Fueling Social and Economic Development. Journal of Small Business Management. https:// doi.org/10.1111/jsbm.12503 
Herrera, F., Guerrero, M., \& Urbano, D. (2018). Entrepreneurship and Innovation Ecosystem's Drivers: The Role of Higher Education Organizations. In J. Leitao, H. Alves, N. Krueger, \& J. Park (Eds.), Entrepreneurial, Innovative and Sustainable Ecosystems. (pp. 109-128). Springer.

Hessels, J., \& van der Zwan, P. (2013). Start-up Motivation and (in)Voluntary Exit, Scales Research Reports, H201309, EIM Business and Policy Research.

Hessels, J., van Gelderen, M., \& Thurik, R. (2008). Entrepreneurial Aspirations, Motivations, and Their Drivers. Small Business Economics. https://doi.org/10.1007/s11187-008-9134-X

Hill, F. M., Leitch, C. M., \& Harrison, R. T. (2006). Desperately Seeking Finance?'. Venture Capital. https://doi.org/10.1080/13691060600555347

Holienkaa, M., Jančovičováa, Z., \& Kovačičová, Z. (2016). Drivers of women entrepreneurship in Visegrad countries: GEM evidence. https://doi.org/10.1016/j.sbspro.2016.05.476

Hsu, D. K., Burmeister-Lamp, K., Simmons, S. A., Foo, M. D., Hong, M. C., \& Pipes, J. D. (2019). I know I can, but I don't fit: Perceived fit, self-efficacy, and entrepreneurial intention. Journal of Business Venturing, 34(2), 311-326.

Humbert, A. L., Drew, E., \& Kelan, E. (2010). Gender Identity and ICT Entrepreneurship in an Irish Context. In Handbook of Research on High-Technology Entrepreneurs, Pines, A.M., Ozbilgin, M.F., Eds., pp 123-141.

Hwang, V., Desai, S., \& Baird, R. (2019). Access to Capital for Entrepreneurs: Removing Barriers Kansas City.

ILO (2020). ILO Monitor 1st Edition. COVID-19 and the world of work: Impact and policy responses. International Labour Organization. Available at: http://www.ilo.org/wcmsp5/groups/public/--dgreports/---dcomm/documents/briefingnote/wcms_738753.pdf

Index of Economic Freedom: Promoting Economic Opportunity and Prosperity by Country http://www. heritage.org/index/. Accessed 24 Jul 2020.

Jennings, J. E., \& Brush, C. G. (2013). Research on Women Entrepreneurs: Challenges to (and from) the Broader Entrepreneurship Literature? ANNALS. https://doi.org/10.5465/19416520.2013.782190

Jones, O., \& Jayawarna, D. (2010). Resourcing New Businesses: Social Networks Venture Capital. https:// doi.org/10.1080/13691061003658886

Kim, P. H., Aldrich, H. E., \& Keister, L. A. (2006). Access (Not) Denied: The Impact of Financial, Human, and Cultural Capital on Entrepreneurial Entryin the United States. Small Business Economics. https://doi.org/10.1007/s11187-006-0007-X

Koster, S., \& Rai, S. K. (2008). Entrepreneurship and Economic Development in a Developing Country: A Case Study of India. The Journal of Entrepreneurship. https://doi.org/10.1177/097135570801700202

Lerner, M., \& Malach-Pines, A. (2011). Gender and Culture in Family Business: A Ten-Nation Study. International Journal of Cross Cultural Management. https://doi.org/10.1177/1470595811399190

Lykke, N. (2010). Feminist Studies: A Guide to Intersectional Theory Methodology and Writing, Routledge.

Malach-Pines, A., Lerner, M., \& Schwartz, D. (2010). Gender Differences in Entrepreneurship: Equality, Diversity and Inclusion in Times of Global Crisis. An International Journal. https://doi.org/10. $1108 / 02610151011024493$

Maniyalath, N., \& Narendran, R. (2016). The Human Development Index Predicts Female Entrepreneurship Rates. International Journal of Entrepreneurial Behavior \& Research, 22(5), 745-766.

Marlow, S., \& Patton, D. (2005). All Credit to Men? Entrepreneurship, Finance, and Gender: Entrepreneurship Theory and Practice, 29(6), 717-735.

Marques, H. (2017). Gender, Entrepreneurship and Development: Which Policies Matter? Development Policy Review. https://doi.org/10.1111/dpr.12206

McGowan, P., Redeker, C. L., Cooper, S. Y., \& Greenan, K. (2012). Female Entrepreneurship and the Management of Business and Domestic Roles: Motivations Entrepreneurship \& Regional Development. https://doi.org/10.1080/08985626.2012.637351

Meyer, N. (2018). Research on female entrepreneurship: Are we doing enough? Polish Journal of Management Studies, 17(2), 158-169.

Millán, J., Congregado, E., \& Román, C. (2014). Entrepreneurship Persistence with and without Personnel: The Role of Human Capital and Previous Unemployment. International Entrepreneurship and Management Journal. https://doi.org/10.1007/s11365-011-0184-1

Minniti, M., \& Arenius, M. (2003). Women in Entrepreneurship Babson College.

Minniti, M., \& Naudé, W. (2010). What Do We Know About the Patterns and Determinants of Female Entrepreneurship Across Countries? European Journal of Development Research, 22(3), 277-293. 
Moore, D. P., \& Buttner, E. H. (1997). Woman Entrepreneurs: Moving beyond the Glass Ceiling, Sage Publications.

Muravyev, A., Talavera, O., \& Schäfer, D. (2009). Entrepreneurs' Gender and Financial Constraints: Evidence from International Data. Journal of Comparative Economics. https://doi.org/10.1016/j.jce. 2008.12.001

Murphy, P. J., Kickul, J., Barbosa, S. D., \& Titus, L. (2007). Expert Capital and Perceived Legitimacy: Female-Run Entrepreneurial Venture Signalling and Performance. The International Journal of Entrepreneurship and Innovation. https://doi.org/10.5367/000000007780808002

Nabi, G., Holden, R., \& Walmsley, A. (2010). Entrepreneurial Intentions among Students: Towards a Refocused Research Agenda. Journal of Small Business and Enterprise Development. https://doi.org/ $10.1108 / 14626001011088714$

Nasiri, N., \& Hamelin, N. (2018). Entrepreneurship Driven by Opportunity and Necessity: Effects of Educations, Gender and Occupation in MENA. Asian Journal of Business Research, 8(2), 57-71.

Naudé, W. (2011). Entrepreneurship is not a binding constraint on growth and development in the poorest countries. World Development. https://doi.org/10.1016/j.worlddev.2010.05.005

Ndikubwimana, J.B., Mukasekuru, A., Ndizeye, I., Mutesi, J., \& Byukusenge, E. (2020). The effect of entrepreneurial orientation on business performance: a comparative study of necessity and opportunity entrepreneurs by gender. Research Square. https://www.researchsquare.com/article/rs73718/v1

Noguera, M., Álvarez, C., Merigó, J. M., \& Urbano, D. (2015). Determinants of Female Entrepreneurship in Spain: An Institutional Approach. Computational and Mathematical Organization Theory, 21(4), 341-355.

Noorderhaven, N., Thurik, R., Wennekers, S., \& van Stel, A. (2004). The Role of Dissatisfaction and per Capita Income in Explaining Self-Employment across 15 European Countries. Entrepreneurship Theory and Practice. https://doi.org/10.1111/j.1540-6520.2004.00057.x

OECD. (2017). Policy brief on women's entrepreneurship. Publications Office of the EU. https://doi.org/ $10.2767 / 50209$

OECD. (2020). Organisation for Economic Cooperation and Development. https://www.oecd-ilibrary. org/. Accessed 24 Jul 2020.

Oosterbeek, H., van Praag, M., \& Ijsselstein, A. (2010). The Impact of Entrepreneurship Education on Entrepreneurship Skills and Motivation. European Economic Review, 54(3), 442-454.

Orser, B. J., Riding, A. L., \& Manley, K. (2006). Women Entrepreneurs and Financial Capital. Entrepreneurship Theory and Practice. https://doi.org/10.1111/j.1540-6520.2006.00140.x

Peña, I., Guerrero, M., \& González-Pernía, J. L. (2015) Global Entrepreneurship Monitor: Informe GEM España 2014, Universidad de Cantabria y Red GEM España.

Peterman, N. E., \& Kennedy, J. (2003). Enterprise Education: Influencing Students' Perceptions of Entrepreneurship. Entrepreneurship Theory and Practice. https://doi.org/10.1046/j.1540-6520.2003.00035.x

Poschke, M. (2013). Entrepreneurs out of Necessity': A Snapshot. Applied Economics Letters, 20(7), $658-663$.

Powell, G. N. (2011). Women and Men in Management. (4th ed.). Sage Publishing.

Pradhan, R. P., Arvin, M. B., Nair, M., \& Bennett, S. E. (2020). The Dynamics among Entrepreneurship, Innovation, and Economic Growth in the Eurozone Countries. Journal of Policy Modeling. https://doi. org/10.1016/j.jpolmod.2020.01.004

Qian, S., Ma, D., \& Miao, C. (2016). Deciding to discover entrepreneurial opportunities: a multi-level investigation based on informational economics and resource dependence theory. Journal of Developmental Entrepreneurship. https://doi.org/10.1142/S1084946716500096

Ramadani, V., Rexhepi, G., Abazi-Alili, H., Beqiri, B., \& Thaçi, A. (2015). A Look at Female Entrepreneurship in Kosovo: An Exploratory Study. Journal of Enterprising Communities: People and Places in the Global Economy. https://doi.org/10.1108/JEC-04-2015-0027

Ratten, V., \& Dana, L. P. (2017). Gendered perspective of indigenous entrepreneurship. Small Enterprise Research. https://doi.org/10.1080/13215906.2017.1289858

Reynolds, P., Bosma, N., Autio, E., Hunt, S., De Bono, N., Servais, I., Lopez-Garcia, P., \& Chin, N. (2005). Global Entrepreneurship Monitor: Data Collection Design and Implementation 1998-2003. Small Business Economics. https://doi.org/10.1007/s11187-005-1980-1

Rubio-Bañón, A., \& Esteban-Lloret, N. (2016). Cultural Factors and Gender Role in Female Entrepreneurship. Suma de Negocios. https://doi.org/10.1016/j.sumneg.2015.12.002 
Sánchez, J. C. (2011). University Training for Entrepreneurial Competencies: Its Impact on Intention of Venture Creation. International Entrepreneurship and Management Journal. https://doi.org/10.1007/ s11365-010-0156-X

Sarfaraz, L., Faghih, N., \& Majd, A. A. (2014). The Relationship between Women Entrepreneurship and Gender Equality. Journal of Global Entrepreneurship Research. https://doi.org/10.1186/2251-7316-2-6

Shane, S., \& Venkataraman, S. (2000). The Promise of Entrepreneurship as a Field of Research. The Academy of Management Review. https://doi.org/10.2307/259271

Shapero, A., \& Sokol, L. (1982). The Social Dimensions of Entrepreneurship. In The Encyclopedia of Entrepreneurship, Kent, C, Sexton, D., Vesper, K., Eds., Prentice Hall: Englewood Cliffs, NJ.

Shaw, E., Marlow, S., Lam, W., \& Carter, S. (2009). Gender and Entrepreneurial Capital: Implications for Firm Performance. International Journal of Gender and Entrepreneurship. https://doi.org/10.1108/ 17566260910942327

Shmailan, A. B. (2016). Compare the Characteristics of Male and Female Entrepreneurs as Explorative Study. Journal of Entrepreneurship \& Organization Management. https://doi.org/10.4172/2169-026X. 10002

Sörensson, A., \& Dalborg, C. (2017). Female entrepreneurs in nature-based businesses: working conditions, well-being, and everyday life situation. Society, Health \& Vulnerability,. https://doi.org/10.1080/20021 518.2017.1306905

Sternberg, R., \& Wennekers, S. (2005). Determinants and effects of new business creation using global entrepreneurship monitor data. Small Business Economics, 24(3), 193-203.

Stoica, O., Roman, A., \& Rusu, V. D. (2020). The Nexus between Entrepreneurship and Economic Growth: A Comparative Analysis on Groups of Countries. Sustainability. https://doi.org/10.3390/su12031186

Sugheir, J., Baughn, C., \& Neupert, K. (2013). Unemployment and New Firm Formation During the Great Recession: The Impact of Prior Levels of Entrepreneurship. International Journal of Business \& Economics Perspectives, 8(2), 22-34.

Terjesen, S., \& Amorós, J. E. (2010). Female Entrepreneurship in Latin America and the Caribbean: Characteristics, Drivers and Relationship to Economic Development. The European Journal of Development Research. https://doi.org/10.1057/ejdr.2010.13

Tewoldebirhan, M., \& Joseph, K. (2019). Unleashing the Power of Women Entrepreneurs: Breaking down the Legal Barriers. World Bank Blogs, https://blogs.worldbank.org/opendata/unleashing-powerwomen-entrepreneurs-breaking-down-legal-barriers

Thurik, A. R., Carree, M. A., van Stel, A., \& Audretsch, D. B. (2008). Does Self-Employment Reduce Unemployment? Journal of Business Venturing. https://doi.org/10.1016/j.jbusvent.2008.01.007

Treichel, M. Z., \& Scott, J. A. (2006). Women-Owned Businesses and Access to Bank Credit: Evidence from Three Surveys since 1987. Venture Capital. https://doi.org/10.1080/13691060500453726

Tyszka, T., Cieślik, J., Domurat, A., \& Macko, A. (2011). Motivation, Self-Efficacy, and Risk Attitudes among Entrepreneurs during Transition to a Market Economy. The Journal of Socio-Economics. https://doi.org/10.1016/j.socec.2011.01.011

Ucbasaran, D., Westhead, P., \& Wright, M. (2008). Opportunity Identification and Pursuit: Does an Entrepreneur's Human Capital Matter? Small Business Economics. https://doi.org/10.1007/s11187-006-9020-3

Urbano, D., Audretsch, D., Aparicio, S., \& Noguera, M. (2019). Does Entrepreneurial Activity Matter for Economic Growth in Developing Countries? . International Entrepreneurship and Management Journal. https://doi.org/10.1007/s11365-019-00621-5

Valliere, D., \& Peterson, R. (2009). Entrepreneurship and Economic Growth: Evidence from Emerging and Developed Countries. Entrepreneurship \& Regional Development. https://doi.org/10.1080/08985 620802332723

van Der Sluis, J., van Praag, M., \& Vijverberg, W. (2008). Education and Entrepreneurship Selection and Performance: A Review of the Empirical Literature. Journal of Economic Surveys. https://doi.org/10.1111/j. 1467-6419.2008.00550.x

van Stel, A., Carree, M., \& Thurik, R. (2005). The effect of entrepreneurial activity on national economic growth. Small Business Economics, 24(3), 311-321.

Vendrell, A. (2012). Las pymes industriales españolas y su endeudamiento. Conocimiento de sus determinantes estructurales. Información Comercial Española, ICE: Revista de economía, 867, 159-174.

Verheul, I., \& Thurik, R. (2001). Start-Up Capital: Does Gender Matter? Small Business Economics. https:// doi.org/10.1023/A:1011178629240

Ward, T. B. (2004). Cognition, Creativity, and Entrepreneurship. Journal of Business Venturing. https://doi. org/10.1016/S0883-9026(03)00005-3 
Wassem, A. (2018). Female Necessity and Opportunity Entrepreneruship: A Studiy of Income Level and Social Profess. Pakistan Journal of Women's Studies, 25(1), 127-149.

Weiler, S., \& Bernasek, A. (2001). Dodging the Glass Ceiling? . The Social Science Journal. https://doi.org/ 10.1016/S0362-3319(00)00111-7

Weitzel, U., Urbig, D., Desai, S., Sanders, M., \& Acs, Z. (2010). The Good, the Bad, and the Talented: Entrepreneurial Talent and Selfish Behavior. Journal of Economic Behavior \& Organization. https://doi. org/10.1016/j.jebo.2010.02.013

Westhead, P., Ucbasaran, D., \& Wright, M. (2005). Decisions, Actions, and Performance: Do Novice, Serial, and Portfolio Entrepreneurs Differ? Journal of Small Business Management. https://doi.org/10.1111/j. 1540-627X.2005.00144.X

Wiklund, J., Nikolaev, B., Shir, N., Food, M.-D., \& Bradleye, S. (2019). Entrepreneurship and well-being: Past, present, and future. Journal of Business Venturing. https://doi.org/10.1016/j.jbusvent.2019.01. 002

Wilson, F., Carter, S., Tagg, S., Shaw, E., \& Lam, W. (2007). Bank Loan Officers' Perceptions of Business Owners: The Role of Gender. British Journal of Management. https://doi.org/10.1111/j.1467-8551. 2006.00508.X

Wu, J., Li, Y., \& Zhang, D. (2019). Identifying women's entrepreneurial barriers and empowering female entrepreneurship worldwide: a fuzzy-set QCA approach. International Entrepreneurship and Management Journal, 15, 905-928.

Wu, Z., \& Chua, J. H. (2011). Second-Order Gender Effects: The Case of U.S. Small Business Borrowing Cost. Entrepreneurship Theory and Practice. https://doi.org/10.1111/j.1540-6520.2012.00503.x

Zhao, H. B., \& Seibert, S. E. (2006). The Big Five Personality Dimensions and Entrepreneurial Status: A Meta-Analytical Review. The Journal of applied psychology. https://doi.org/10.1037/0021-9010.91.2. 259

Publisher's Note Springer Nature remains neutral with regard to jurisdictional claims in published maps and institutional affiliations.

\section{Authors and Affiliations}

\section{Isabel Martínez-Rodríguez ${ }^{1}$ (D) · Consolación Quintana-Rojo $•$ Pedro Gento ${ }^{1}$. Fernando-Evaristo Callejas-Albiñana ${ }^{1}$ D}

Consolación Quintana-Rojo

consolacion.quintana@uclm.es

Pedro Gento

pedro.gento@uclm.es

Fernando-Evaristo Callejas-Albiñana

fernando.callejas@uclm.es

1 Faculty of Law and Social Sciences, University of Castilla_La Mancha, Ronda de Toledo S/N., 13071 Ciudad Real, Spain 